\title{
STUDI KOMPERATIF BRAND IMAGE PRODUK LAPTOP ASUS DAN ACER PADA MAHASISWA FAKULTAS EKONOMI UNIVERSITAS PENDIDIKAN GANESHA TAHUN 2017.
}

\author{
Ketut Pande Ardika ${ }^{1}$, Anjuman Zukhri ${ }^{2}$, Kadek Rai Suwena ${ }^{3}$ \\ Jurusan Pendidikan Ekonomi \\ Universitas Pendidikan Ganesha \\ Singaraja, Indonesia
}

\begin{abstract}
e-mail : pandeardika69@gmail.com ${ }^{1}$, anjumanukhri09@gmail.com², kadek suwena@yahoo.co.id ${ }^{3}$
\end{abstract}

\begin{abstract}
Abstrak
Penelitian ini bertujuan untuk mengetahui perbedaan Brand Image laptop Acer dan Asus pada mahasiswa Fakultas Ekonomi tahun 2017 ditinjau dari dimensi keunggulan assosiasi merek, kekuatan assosiasi merek, dan keunikan assosiasi merek. Jenis penelitian ini merupakan penelitian kompareatif. Populasi dalam penelitian ini adalah mahasiswa Fakultas Ekonomi yang memiliki laptop Acer dan Asus berjumlah 637. Sampel berjumlah 186 orang, dan diambil dengan teknik proportionate random sampling. Data dikumpulkan dengan menggunakan metode kuesioner, dan dianalisis menggunakan teknik analisis Independent-Sample T-test. Hasil penelitian ini menunjukkan bahwa ada perbedaan yang signifikan tentang Brand Image ditinjau dari dimensi keunggulan assosiasi merek dengan skor (Sig.) sebesar 0,003 $<0,05$. Dilihat dari dimensi kekuatan assosiasi merek tidak terdapat perbedaan dilihat dari skor (Sig.) sebesar 0,362 >0,05. Dilihat dari dimensi keunikan assosiasi merek terdapat perbedaan dilihat dari skor (Sig.) sebesar 0,000 >0,05.
\end{abstract}

Kata kunci : Merek, Brand Image, Assosiasi Merek.

\begin{abstract}
This study attempts to tell the difference Brand Image Laptop acer and asus in students of the faculty economic 2017 In terms of the dimensions of the associated brands, the power associated brands, associated with the brand. This type of research is a comparative study. The population of the research is students of the faculty economic have a laptop acer and asus were 637. The sampel amounted to 186 people and taken to technique proportionate random sampling. Data were collected by using the method the questionnaire, and analyzed using analysis techniques Independent-Sample T-test. The result of this research shows that there are significant differences about the Brand Image in terms of excellence brand dimension associated with the score (Sig.) of 0,003 $<0,05$. Judging from the dimensions of the strength of the brand association there is no difference seen from the score (Sig.) of 0,362 > 0,05. Judging from the uniqueness dimension of the brand association there is a difference seen from the score (Sig.) of $0,000>0,05$.
\end{abstract}

Keywords: Brand, Brand Image, Brand Associations.

\section{PENDAHULUAN}

Perkembangan teknologi dalam era modern saat ini menyebabkan banyak teknologi-teknologi baru yang tercipta. Ilmu pengetahuan teknologi dan informasi serta komunikasi yang terus berkembang 
dikehidupan sehari-hari dimana ditandai dengan perubahan yang sangat cepat disegala bidang khususnya pada bidang teknologi informasi. Diantara perkembangan teknologi informasi, laptop merupakan salah satu teknologi yang dimana dari sebuah bentuk komputer yang besar menjadi komputer yang portable atau mudah dibawa ke mana saja. Pada tahun 2017 beberapa merek-merek laptop yang beredar di pasaran diataranya , Acer, Asus, Toshiba, HP, Sony, Samsung, dan Macbook. Berbagai merek produk ditawarkan oleh para produsen dengan keunggulan masing-masing. Para produsen laptop memang gencar menawarkan produk mereka dengan melakukan berbagai promo untuk menarik hati para konsumennya. Dari banyaknya merek laptop dan juga memiliki kelebihan dan kekurangan yang dimiliki oleh produk laptop membuat para calon konsumen yang akan memutuskan untuk membeli akan melihat dari berbagai aspek. Menurut Kotler dan Amstrong (2006:275) "Merek adalah nama, istilah, tanda, lambang, atau desain atau kombinasinya yang dimaksudkan untuk mengidentifikasi suatu produk barang atau jasa dari seorang penjual atau sekelompok penjual dan untuk membedakannya dari barangbarang yang dihasilkan oleh pesaing. Dengan brand atau merek tersebut, perusahaan mengharapkan supaya konsumen mempunyai kesan positif pada barang atau jasa yang dihasilkan (Brand Image)."

Lamb (2001) berpendapat bahwa "merek adalah suatu nama istilah, simbol, desain atau gabungan keempatnya yang mengidentifikasikan produk para penjual dan membedakannya dari produk pesaing." Sedangkan menurut Keller dalam Tjiptono (2005), merek adalah produk yang mampu memberikan dimensi tambahan yang secara unik membedakannya dari produk-produk lain yang dirancang untuk memuaskan kebutuhan serupa. Menurut UndangUndang No 15 Tahun 2001 pengertian merek adalah tanda yang berupa gambar, nama, kata, huruf-huruf, angka-angka, susunan warna, atau kombinasi dari unsur-unsur tersebut yang memiliki daya pembeda dan digunakan dalam kegiatan perdagangan barang atau jasa. Dari seluruh definisi yang sudah dijelaskan sebelumnya, maka dapat disimpulkan bahwa merek merupakan suatu bagian dari produk yang memiliki peran sebagai identitas dan juga sebagai bahan pembeda dari produk pesaing, baik itu berupa istilah, tanda, simbol, ataupun kombinasi dari semuanya. Salah satu aspek yang sering kali menjadi acuan bagi para konsumen sebelum melakukan pembelian adalah dengan melihat citra merek itu sendiri. Merek yang bagus dan telah dikenal oleh masyarakat masyarakat suatu aset yang sangat berharga bagi perushaan. Menurut Terence (2003:8) merek mempunyai beberapa peran bagi perusahaan yang memasarkannya sebagai berikut. Pertama peran ekonomi yang artinya merek memungkinkan perusahaan untuk mencapai skala ekonomis dengan memproduksi merek tersebut secara masal dan merek yang sukses dapat menjadi penghambat bagi pesaing yang ingin memperkenalkan merek mereka. Kedua peran strategis yang artinya merek dapat menjadi strategi pemasaran yaitu menjadi bahan pembeda antara produk yang ditawarkan suatu perusahaan dengan merek - merek saingannya.

Citra merek (Brand Image) sebagai seperangkat keyakinan, ide, dan kesan yang dimiliki oleh seseorang terhadap suatu merek (Simamora, 2004). Menurut Keller (dalam Alfian 2012:26) mengemukakan faktor-faktor terbentuknya citra merek yaitu, pertama keunggulan produk merupakan salah satu faktor pembentuk Brand Image, dimana produk tersebut unggul dalam persaingan, kedua kekuatan merek merupakan asosiasi merek tergantung pada bagaimana informasi masuk ke dalam ingatan konsumen dan bagaimana proses bertahan sebagai bagian dari citra merek, dan ketiga keunika merek adalah asosiasi terhadap suatu merek mau tidak mau harus terbagi dengan merek-merek lain.

Selain itu menurut Ferindadewii (2008) berpendapat bahwa citra merek adalah merupakan konsep yang diiciptakan oleh konsumen karena alasan 
subjektif dan emosi pribadinya. Ditambahkan citra merek adalah persepsi tentang merek yang digambarkan oleh asosiasi merek yang ada dalam ingatan konsumen. Citra yang baik terhadap suatu barang akan meningkatkan persepsi yang baik pula terhadap seseorang.

Brand Image atau Citra merek merupakan serangkaian asosiasi (persepsi) yang ada dalam benak konsumen terhadap suatu merek, biasanya terorganisasi menjadi suatu makna. Hubungan terhadap suatu merek akan semakin kuat jika didasarkan pada pengalaman dan mendapat banyak informasi. Citra atau asosiasi merepresentasikan persepsi yang bisa merefleksikan kenyataan yang objektif ataupun tidak. Citra yang terbentuk dari asosiasi (presepsi) inilah yang mendasari keputusan membeli bahkan loyalitas merek (brand loyalty) dari konsumen. Citra merek meliputi pengetahuan dan kepercayaan akan atribut merek (aspek kognitif), konsekuensi dari penggunaan merek tersebut dan situasi penggunaan yang sesuai, begitu juga dengan evaluasi, perasaan dan emosi yang dipresepsikan dengan merek tersebut (aspek Afektif).

Menurut Ali (2013) adapun manfaat citra merek yang kuat bagi pelanggan dan perusahaan adalah sebagai berikut. Pertama manfaat bagii pelanggan ada tiga alasan sekaligus manfaat penting bagi pelanggan dari sebuah merek yang memiliki citra positif yaitu sebagai berikut, yang pertama sebuah merek yang kuat akan memudahkan konsumen untuk mengevaluasi, menimbang dan membuat keputusan membeli dari rincian nilai-nilai yang terkait dengan kinerja produk, harga, pengiriman, garansi dan lain-lain. Merek dengan image yang kuat adalah sintesis bagi pembeli dari segala sesuatuyang ditawarkan oleh pemasok, mengurangi risiko keputusan pembelian yang rumit terutama untuk produk berbasis teknologi, yang kedua sebuah merek yang kuat membuat pelanggan merasa percaya diri dalam pilihan mereka, menyederhanakan pilihan sehari-hari (untuk kebutuhan dasar). Orang-orang berbelanja di mall atau di toko-toko yang branded sering tidak membandingkan produk dengantempat lain karena mereka percaya merek. Branding yang kuat mampu menciptkanan hubungan kepercayaan jangka panjang, aksebilitas, kepercayaan, rasa aman dan kenyamanan yang sama dalam sepanjang hidup mereka, dan yang ketiga sebuah merek yang kuat membuat pelanggan merasa lebih puas dengan pembelian mereka, memberikan manfaat dan ikatan emosional (untuk produk perawatan pribadi). Kualitas persepsi sering mereka terjemahkan menjadi rasa yang membuat pelanggan lebih bahagia disbanding jika produk berasal dari pemasok yang tidak mereka ketahui, karenanya brand yang kuat mampu menawarkan ikatan komunikasi tertentu, terutama produkproduk yang terkait dengan image. Pada akhirnya pemasaran yang berhasil adalah kemampuannya meyakinkian pelanggan bahwa mereka tidak khawatir menggunakan produk yang bermerek kuat. Selain manfaat bagi pelanggan citra sebuah merek bermanfaat juga bagi perusahaan yaitu sebagai berikut, yang pertama, harga premium astinya adalah sebuah merek dengan citra yang positif akan menciptkan margin yang lebih besar dan walaupun ada tekanan untuk mejual dengan harga rendah atau menawarkan diskon, akan tetapi relatif tidak atau kurang rentan terhadap kekuatan kompetitif, selanjutnya yang kedua klaim produk artinya adalah sebuah merek dengan citra yang kuat akan menciptakan orang-orang melakukan permintaan secara khusus, orang akan mencari merek yang inginkan, selanjutnya adalah yang ketiga yaitu komunikasi parrier yyang artinya adalah sebuah merek yang kuat mampu bertindak sebagai penghalang untuk beralih ke produk pesaing. Brand adalah pertahanan yang berlanngsung secara permanen, selajutnya yang keempat yaitu komunkasi pemasaran lebih mudah diterima. Pemasaraan positif tentang suatu merek akan mengakibatkan orang mampu menerima klaim baru terhadap kinerja produk dan mereka akan welcome, sehingga lebih mudah "dibujuk" untuk membeli banyak, selanjutnya yang kelima yaitu pengembangan merek yang 
artinya sebuah merek yang terkena menjadi platform untuk pengembangan atau menambah produk baru karena beberapa aspek dari citra positif yang berpengaruh dan membantu dalam peluncuran produk baru, selanjutnya yang keenam yaitu kepuasan pelanggan yang artinya sebuah citra positif akan memberikan tingkat kepuasan pelanggan ketika mereka menggunakan produk. Mereka akan merasa tingkat kepuasan pelanggan ketika mereka menggunakan produk. Mereka akan merasa lebih yakin membelinya. Pelanggan tidak menemukan alasan untuk membeli merek lain atau pemasok lain, selanjutnya yang ketujuh yaitu jaringan distribusi yang arinya sebuah merek yang kuat lebih mudah dijual ke pedagang grosir dan distributor tabg sangat responsive terhadap apa yang diinginkan oleh pelanggan mereka, selanjutnya yang kedelapan yaitu perizinan dan peluang yang artinya sebuah merek yang kuat dapat mendukung trasaksi usaha patungan atau mengizinkan merek dilisensikan untuk digunakan dalam aplikasi baru atau Negara lain (terbuka bag semua orang atau negara manapun), selanjutnya yang kesembilan yaitu nilai harga jual yang tinggi yang artinya sebuah perusahaan dengan nama merek yang baik akan mendapatkan premi yang lebih tinggi jika dijual.

Menurut Keller (2003) mengemukakan faktor-faktor terbentuknya citra merek sebagai berikut. Yang pertama keunggulanan assosisasi merek (Favorability of brand association) yang artinya keunggulanan produk merupakan salah satu faktor pembentuk Brand Image, dimana produk tersebut unggul dalam persaingan dikarenakan keunggulan kualitas (model dan kenyamanan) dan ciri khas itulah yang menyebabkan suatu produk mempunyai daya tarik tersendiri bagi konsumen. Favorability of brand association adalah asosiasi merek dimana konsumen percaya bahwa atribut dan manfaat yang diberikan oleh merek akan dapat memenuhi atau memuaskan kebutuhan dan keinginan mereka sehingga mereka membentuk sikap positif terhadap merek. Selanjutnya yang kedua yaitu kekuatan asosiasi merek (Strength of brand association) yang artinya Kekuatan merek merupakan asosiasi merek tergantung pada bagaimana informasi masuk kedalam ingatan konsumen dan bagaimana proses bertahan sebagai bagian dari citra merek. Kekuatan asosiasi merek ini merupakan fungsi dari jumlah pengolahan informasi yang diterima pada proses recoding. Ketika seorang konsumen secara aktif menguraikan arti informasi suatu produk atau jasa maka akan tercipta asosiasi yang semakin kuat pada ingatan konsumen. Pentingnya asosiasi merek pada ingatan konsumen tergantung pada bagaimana suatu merek tersebut dipertimbangkan. Selanjutnya yang ketiga yaitu keunikan asosiasi merek (Uniqueness of brand association) yang artinya Keunikan merek adalah asosiasi terhadap suatu merek mau tidak mau harus terbagi dengan merek-merek lain. Oleh karena itu, harus diciptakan keunggulan bersaing yang dapat dijadikan alasan bagi konsumen untuk memilih suatu merek tertentu. Dengan memposisikan merek lebih mengarah kepada pengalaman atau keuntungan diri dari image produk tersebut. Dari perbedaan yang ada, baik dari produk, pelayanan, personil, dan saluran yang diharapkan memberikan perbedaan dari pesaingnya, yang dapat memberikan keuntungan bagi produsen dan konsumen.

Pengukuran Citra Merek Menurut pendapat Kotler \& Keller (dalam Prabowo 2013) pengukuran citra merek adalah subjektif, artinya tidak ada ketentuan baku untuk pengukuran citra merek (Brand Image). Bahwa pengukuran citra merek dapat dilakukan berdasarkan pada aspek sebuah merek yaitu yang pertama strengthness (Kekuatan) yang atinya strengthness (kekuatan) dalam hal ini adalah keunggulan-keunggulan yang dimiliki oleh merek yang bersifat fisik dan tidak ditemukan pada merek lainnya. Keunggulan merek ini mengacu pada atribut-atribut fisik atas merek tersebut sehingga biasa dianggap sebagai sebuah kelebihan dibandingkan dengan merek lain, yang termasuk pada kelompok strength ini antara lain: fisik produk, keberfungsian semua fasilitas produk, 
harga produk, maupun penampilan fasilitas pendukung dari produk tersebut. Selanjutnya yang kedua uniqueness (Keunikan) yang artinya Uniqueness (keunikan) adalah kemampuan untuk membedakan sebuah merek di antara merek-merek lainnya. Kesan unik ini muncul dari atribut produk, menjadi kesan unik berarti terdapat diferensiasi antara produk satu dengan produk lainnya. Termasuk dalam kelompok unik ini antara lain: variasi layanan yang biasa diberikan sebuah produk, variasi harga dari produkproduk yang bersangkutan maupun diferensiasi dari penampilan fisik sebuah produk, dan yang terakhir Favorable (Kesukaan) yang artinya Favorable (kesukaan) mengarah pada kemampuan merek tersebut agar mudah diingat oleh konsumen, yang termasuk dalam kelompok favorable ini antara lain: kemudahan merek tersebut diucapkan, kemampuan merek untuk tetap diingat oleh pelanggan, maupun kesesuaian antara kesan merek di benak pelanggan dengan citra yan diinginkan perusahaan atas merek yang bersangkutan.

Mahasiswa dalam keseharian perkuliahannya akan pasti menggunakan laptop untuk menunjang aktivitasnya, baik itu untuk membuat tugas dan membuat presentasi sehingga laptop sangatlah penting bagi mahasiswa. Dari observasi awal yang saya lakukan di kalangan mahasiswa Fakultas Ekonomi Universitas Pendidikan Ganesha dari 100 orang yang diwawancarai acak mengenai merek laptop yang mereka gunakan yaitu 45 orang menggunakan laptop merek Acer, 38 orang menggunaan laptop Asus, 17 orang menggunakan merek laptop selain Acer dan Asus. Dan dari observasi awal yang sudah saya lakukan di Fakultas Ekonomi Universitas Pendidikan Ganesha diamana laptop Acer dan Asus paling banyak digunakan padahal masih banyak merek laptop yang lain. Adapun tujua dari penelitian sebagai berikut, pertama untuk mengetahui ada perbedaan yang signifikan Brand Image laptop Acer dan Asus pada mahasiswa Jurusan Pendidikan Ekonomi tahun 2017 ditinjau dari dimensi keunggulan assosiasi merek, kedua untuk mengetahui ada perbedaan yang signifikan Brand Image laptop Acer dan Asus pada mahasiswa Jurusan Pendidikan Ekonomi tahun 2017 ditinjau dari dimensi kekuatan assosiasi merek, dan ketiga untuk mengetahui ada perbedaan yang signifikan Brand Image laptop Acer dan Asus pada mahasiswa Jurusan Pendidikan Ekonomi tahun 2017 ditinjau dari dimensi keunikan assosiasi merek.

\section{METODE}

Jenis penelitian ini merupakan jenis penelitian komperatid. Penelitian ini dilaksanakan di Fakultas Ekonomi Universitas Pendidikan Ganesha yang beralamat di Jalan Udayana No. 11, Singaraja, Bali. Definisi operasional yang digunakan dalam penelitian ini ada tiga yaitu sebagai berikut, pertama keunggulan assosiasi merek, kedua kekuatan assoisasi merek, ketiga keunikan assosiasi merek. Pengumpulan data dilakukan dengan metode kuesioner dalam penelitian ini disebarkan kepada mahsiswa Fakultas Ekonomi yang menggunakan laptop Acer sebanyak 637 dan mahasiswa yang menggunakan laptop Asus sebanyak 637. Mengingat jumlah populasi yang cukup banyak maka dari sekian banyak jumlah populasi diambil sebagian untuk dijadikan sampel, untuk menentukan jumlah sampel dari sautu populasi digunakan rumus Slovin (Umar: 2005) adalah sebagai berikut.

$n=\frac{N}{1+N(e)^{2}}$

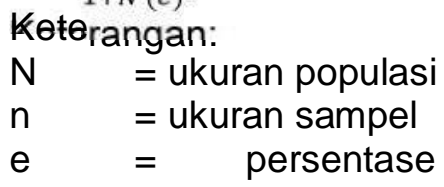

ketidaktelitian (presisi) karena k pengambilan (pampel yang masih dapat ditolerir, dalam hal ini $10 \%$.

Berdasarkan rumus di atas, maka jumlah sampel yang akan digunakan dalam penelitian ini dapat dihitung sebagai berikut.

$\mathrm{N}=637$

$e=10 \%$

$\mathrm{n}=\frac{637}{1+637(10 \%)^{2}}$

$\mathrm{n}=\frac{637}{13 ; 74}$

$\mathrm{n}=\mathrm{9} 272$ 
p-ISSN : 2599-1418

e-ISSN : 2599-1426

Setelah dilakukan perhitungan, maka dari jumlah populasi sebanyak 637 orang, Berdasarkan rumus, sampel yang dapat diambil dari populasi adalah sebanyak 92,72 bila dibulatkan, maka banyaknya sampel adalah 93 mahasiswa. Teknik pengambilan sampel dengan menggunakan teknik Porpotonate Random Sampling. Jenis data yang digunakan dalam penelitian ini adalah data kuantitatif. Data kuantitatif dalam penelitian ini berupa data yang diperoleh dari responden (mahasiswa) Fakultas Ekonomi Universitas Pendidikan Ganesha mengenai Brand Image laptop Acer dan Asus. Sumber data yang digunakan dalam penelitian ini berupa data primer dan data sekunder. Data primer dalam penelitian ini berupa jawaban responden dari mahasiswa Fakultas Ekonomi Universitas Pendidikan Ganesha. Data sekunder dalam penelitian ini berupa jumlah data mahasiswa Fakultas Ekonomi dan literatur yang mendukung penelitian penulis dari karya ilmiah lain yang topiknya hampir sama dengan penelitian yang penulis lakukan. Dalam melaksanakan penelitian, peneliti menggunakan metode kuisioner dan dokumentasi.

Kueisioner digunakan untuk memperoleh data mengenai Brand Image laptop Acer dan Asus pada Mahasiswa Fakultas Ekonomi Universitas Pendidikan Ganesha. Dokumentasi digunakan untuk
Jurnal Pendidikan Ekonomi Undiksha

Volume 10 No. 1 Tahun 2018

memperoleh data jumlah data mahasiswa Fakultas Ekonomi Universitas Pendidikan Ganesha.

Teknik analisis data yang digunakan dalam penelitian ini adalah Analisis Statistik Komparatif, analisis ini dimaksudkan untuk menguji apakah ada perbedaan yang signifikan Brand Image laptop Acer dan Asus pada Mahasiswa Fakultas Ekonomi Universitas Pendidikan Ganesha. Penelitian ini menggunakan analisis Independent-Sample T-Test. Adapun keputusan pengujian t-test $\mathrm{Ho}$ diterima atau ditolak, maka digunakan kreteria uji tabel sebagai berikut. Dasar Pengambilan keputusan dalam teknik analisis ini adalah apabila nilai signifikan atau Sig. (2-tailed) > 0,05, maka $\mathrm{HO}$ diterima dan $\mathrm{Ha}$ ditolak, dan jika nilai signifikan atau Sig. (2-tailed) < 0.05, maka $\mathrm{HO}$ ditolak dan Ha diterima.

\section{HASIL DAN PEMBAHASAN \\ Hasil}

Perbedaan Brand Image Laptop Acer dan Asus ditinjau dari dimensi Keunggulan Assosiasi Merek.

Berdasarkan penelitian yang dilakukan di Fakultas Ekonomi Universitas Pendidikan Ganesha Tahun 2017 di peroleh data mengenai perbedaan Brand Image laptop Acer dan Asus ditinjau dari keunggulan assosiasi merek terlihat dalam tabel

Tabel 1. Group Statistic Brand Image Laptop Acer dan Asus ditinjau dari dimensi Keunggulan Assosiasi Merek.

\begin{tabular}{crcccc}
\hline & & & & \\
\cline { 3 - 5 } Kelompok & $N$ & & Mean & Deviation & Std. Error \\
Keunggulan & Mean \\
Kelompok Acer & & 93 & 12.0829 & 2.75683 & .28587 \\
Kelompok Asus & & 93 & 10.9482 & 2.39341 & .24818 \\
\cline { 3 - 6 }
\end{tabular}

Dari tabel 1 dapat dilihat bahwa rata-rata Brand Image laptop Acer dan Asus pada mahasiswa Fakultas Ekonomi Universitas Pendidikan Ganesha ditinjau dari dimensi keunggulan assosiasi merek yaitu menunjukkan bahwa Brand Image laptop Acer sebesar 12,0829 dan Brand Image laptop asus sebesar 10,9482. Untuk menguji signifikan perbedaan digunakan analisis uji hipotesis yaitu analisis yang dimaksudkan untuk menguji hipotesis yang diajukan dalam penelitian ini, sehingga hipotesis tersebut dapat diterima kebenarannya atau ditolak kebenarannya. Berdasarkan analisis uji Independent Sample t-test dengan bantuan program SPSS 16.00 for windows dipat dilihat pada tabel 2. 
Tabel 2. Hasil analisis uji Independent Sample t-test

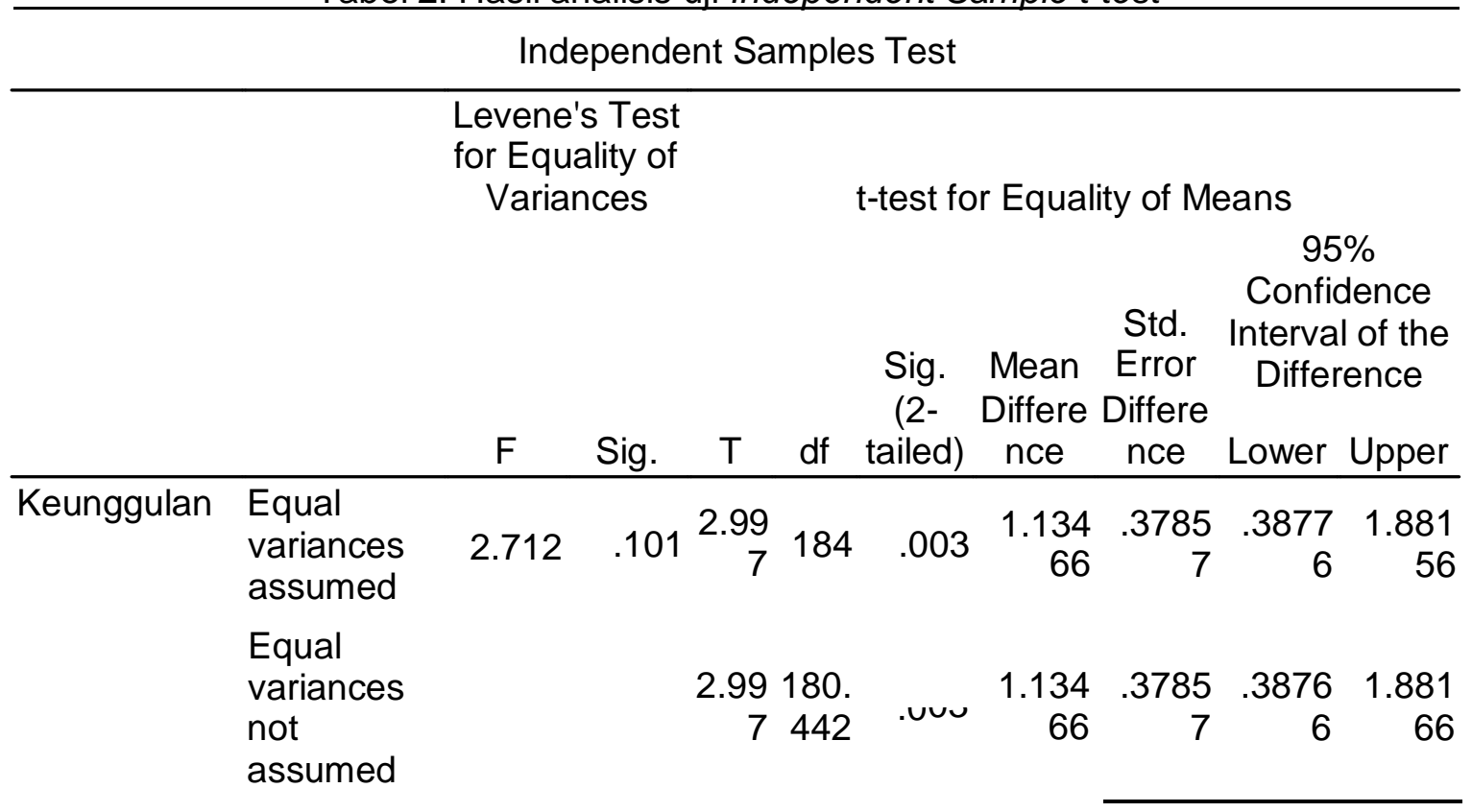

Dari tabel 2 berdasarkan hasil analisis uji Independent Sample t-test dengan menggunakan bantuan SPSS 16.00 for windows, diperoleh nilai $t_{\text {hitung }}$ sebesar 2,997 dengan probalitas (Sig.) sebesar 0,003 . Karena probabilitas (Sig.) $0,003<$ 0,05 maka $\mathrm{HO}$ diterima Ha ditolak. Artinya terdapat perbedaan yang signifikan antara Brand Image laptop Acer dan Asus pada mahasiswa Fakultas Ekonomi Universitas
Pendidikan Ganesha ditinjau dari dimensi keunggulan assosiasi merek.

Perbedaaan Brand Image Laptop Acer dan Asus ditinjau dari dimensi Kekuatan Assosiasi Merek.

Berdasarkan penelitian yang dilakukan di Fakultas Ekonomi Universitas Pendidikan Ganesha Tahun 2017 di peroleh data mengenai perbedaan Brand Image laptop Acer dan Asus ditinjau dari kekuatan assosiasi merek terlihat dalam tabel

Tabel 3. Group Statistic Brand Image Laptop Acer dan Asus ditinjau dari dimensi Kekuatan Assosiasi Merek.

Group Statistics

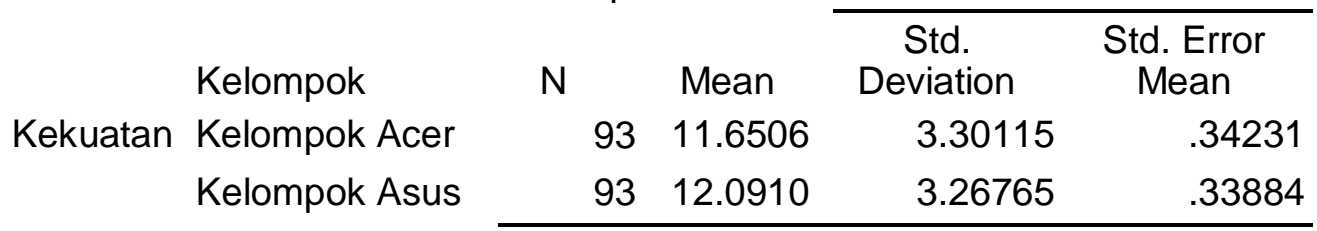

Dari tabel 3 dapat dilihat bahwa rata-rata Brand Image laptop Acer dan Asus pada mahasiswa Fakultas Ekonomi Universitas Pendidikan Ganesha ditinjau dari dimensi keunggulan assosiasi merek yaitu menunjukkan bahwa Brand Image laptop Acer sebesar 11,6506 dan Brand
Image laptop asus sebesar 12,0910. Untuk menguji signifikan perbedaan digunakan analisis uji hipotesis yaitu analisis yang dimaksudkan untuk menguji hipotesis yang diajukan dalam penelitian ini, sehingga hipotesis tersebut dapat diterima kebenarannya atau ditolak 
p-ISSN : 2599-1418

e-ISSN : 2599-1426

kebenarannya. Berdasarkan analisis uji Independent Sample t-test dengan
Jurnal Pendidikan Ekonomi Undiksha

Volume 10 No. 1 Tahun 2018

bantuan program SPSS 16.00 for windows

dipat dilihat pada tabel 4.

Tabel 4. Hasil analisis uji Independent Sample t-test

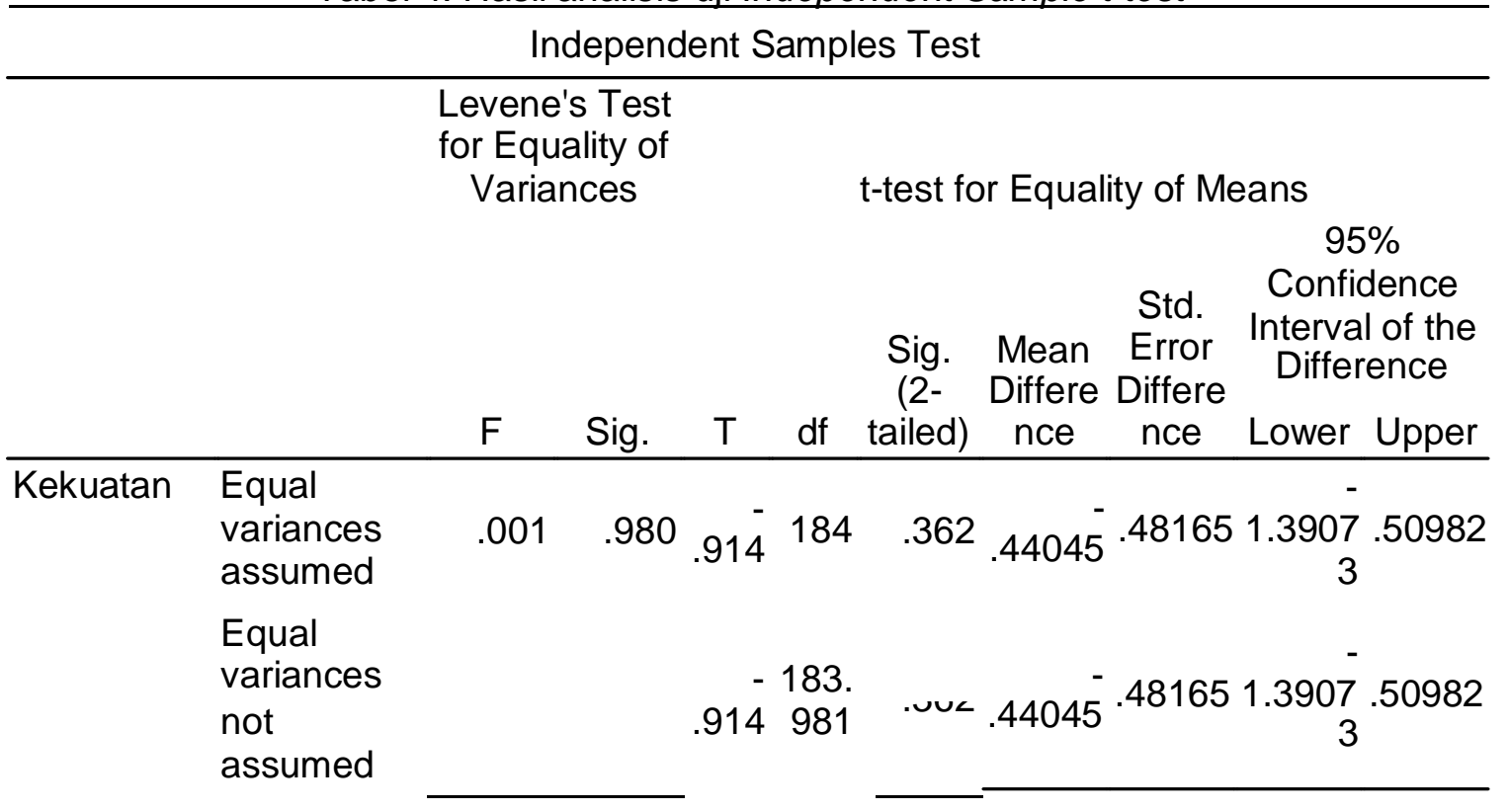

Dari tabel 4 berdasarkan hasil analisis uji Independent Sample t-test dengan menggunakan bantuan SPSS 16.00 for windows, diperoleh nilai $t_{\text {hitung }}$ sebesar -0,914 dengan probalitas (Sig.) sebesar 0.362. Karena probabilitas (Sig.) $0,362>0.05$ maka H0 ditolak Ha diterima. Artinya tidak terdapat perbedaan yang signifikan antara Brand Image laptop Acer dan Asus pada mahasiswa Fakultas Ekonomi Universitas Pendidikan Ganesha ditinjau dari dimensi kekuatan assosiasi merek.

Perbedaan Brand Image Laptop Acer dan Asus ditinjau dari dimensi Keunikan Assosiasi Merek.

Berdasarkan penelitian yang dilakukan di Fakultas Ekonomi Universitas Pendidikan Ganesha Tahun 2017 di peroleh data mengenai perbedaan Brand Image laptop Acer dan Asus ditinjau dari keunikan assosiasi merek terlihat dalam tabel

Tabel 5. Group Statistic Brand Image Laptop Acer dan Asus ditinjau dari dimensi Keunikan Assosiasi Merek.

Group Statistics

\begin{tabular}{|c|c|c|c|c|c|}
\hline \multirow{3}{*}{ Keunikan } & Kelom & $\mathrm{N}$ & Mean & $\begin{array}{c}\text { Std. } \\
\text { Deviation }\end{array}$ & $\begin{array}{l}\text { Std. Error } \\
\text { Mean }\end{array}$ \\
\hline & Kelompok Acer & 93 & 24.3826 & 3.37765 & .35025 \\
\hline & Kelompok Asus & 93 & 22.1437 & 3.05027 & .31630 \\
\hline
\end{tabular}

Dari tabel 5 dapat dilihat bahwa rata-rata Brand Image laptop Acer dan Asus pada mahasiswa Fakultas Ekonomi Universitas Pendidikan Ganesha ditinjau dari dimensi keunikan assosiasi merek yaitu menunjukkan bahwa Brand Image laptop
Acer sebesar 24,3826 dan Brand Image laptop asus sebesar 22,1437.

Untuk menguji signifikan perbedaan digunakan analisis uji hipotesis yaitu analisis yang dimaksudkan untuk menguji hipotesis yang diajukan dalam 
p-ISSN : 2599-1418

e-ISSN : 2599-1426

penelitian ini, sehingga hipotesis tersebut dapat diterima kebenarannya atau ditolak kebenarannya. Berdasarkan analisis uji
Jurnal Pendidikan Ekonomi Undiksha

Volume 10 No. 1 Tahun 2018

Independent Sample t-test dengan bantuan program SPSS 16.00 for windows dipat dilihat pada tabel 6 .

Tabel 6. Hasil analisis uii Independent Sample t-test

\begin{tabular}{|c|c|c|c|c|c|c|c|c|c|}
\hline \multicolumn{10}{|c|}{ Independent Samples Test } \\
\hline & & \multicolumn{2}{|c|}{$\begin{array}{l}\text { Levene's Test } \\
\text { for Equality of } \\
\text { Variances }\end{array}$} & \multirow{3}{*}{\multicolumn{2}{|c|}{ df }} & \multirow{2}{*}{\multicolumn{4}{|c|}{ 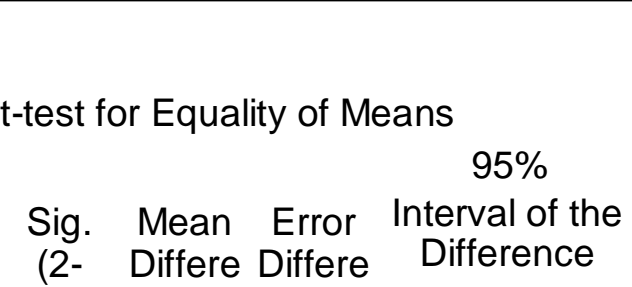 }} \\
\hline & & \multirow[b]{2}{*}{ ᄃ } & \multirow[b]{2}{*}{ Sig. } & & & & & & \\
\hline & & & & & & tailed) & nce & nce & Lower Upper \\
\hline \multirow[t]{2}{*}{$\begin{array}{l}\text { Keu } \\
\text { nika } \\
\text { n }\end{array}$} & $\begin{array}{l}\text { Equal } \\
\text { variances } \\
\text { assumed }\end{array}$ & 1.176 & .280 & $\begin{array}{r}4.74 \\
4\end{array}$ & 184 & .000 & $\begin{array}{r}2.2388 \\
7\end{array}$ & .47193 & $\begin{array}{rr}1.3077 & 3.1699 \\
8 & 6\end{array}$ \\
\hline & $\begin{array}{l}\text { Equal } \\
\text { variances } \\
\text { not } \\
\text { assumed }\end{array}$ & & & $\begin{array}{r}4.74 \\
4\end{array}$ & $\begin{array}{r}182 . \\
120\end{array}$ & .000 & $\begin{array}{r}2.2388 \\
7\end{array}$ & .47193 & $\begin{array}{rr}1.3077 & 3.1700 \\
2 & 2\end{array}$ \\
\hline
\end{tabular}

Dari tabel 6 berdasarkan hasil analisis uji Independent Sample t-test dengan menggunakan bantuan SPSS 16.00 for windows, diperoleh nilai $t_{\text {hitung }}$ sebesar 4.744 dengan probalitas (Sig) sebesar 0,000. Karena probabilitas (Sig.) $0,000<0,05$ maka H0 diterima Ha ditolak. Artinya terdapat perbedaan yang signifikan antara Brand Image laptop Acer dan Asus pada mahasiswa Fakultas Ekonomi Universitas Pendidikan Ganesha ditinjau dari dimensi keunggulan assosiasi merek.

\section{Pembahasan}

Berdasarkan dari hasil penelitan yang telah dilakukan pada mahasiswa Fakultas Ekonomi Universitas Pendidikan Ganesha mengenai perbedaan Brand Image laptop Acer dan Asus ditinjau dari Dimensi keunggualan asosiasi merek, kekuatan asosiasi merek, dan keunikan asosiasi merek menunjukan bahwa terdapat perbedaan. Dari penelitan terdapat jumlah populasi sebesar 637 untuk populasi Acer dan 637 untuk populasi Asus. Dari populasi tersebut didapat sampel sebesar 186 responden yang dibagi menjadi 93 untuk responden Acer dan 93 untuk responden Asus.

Adapun dari hasil penelitian perbedaan Brand Image yang ditinjau dari Dimensi keuunggulan asosiasi merek didapat hasil yaitu $\mathrm{H} 01$ diterima dan $\mathrm{Ha} 1$ ditolak. Artinya ada perbedaan yang signifian antara Brand Image laptop Acer dan Asus ditinjau dari Dimensi keunggulan asosiasi merek. Dari hasil penelitian diperoleh laptop Acer lebih unggul dari pada laptop Asus. Menurut para responden, mereka berpendapat bahwa Acer lebih unggul dari segi kualitas yang dapat dilihat dari kinerja laptop pada saat digunakan sehingga mampu menambahkan rasa percaya diri seseorang ketika menggunakan produk laptop tersebut. Hal ini sesuai dengan teori yang diungkapkan oleh Keller (2003) tentang keunggulan asosiasi merek yaitu : dimana produk tersebut unggul dalam persaingan dikarenakan keunggulan kualitas (model dan kenyamanan) dan ciri khas itulah yang menyebabkan suatu produk mempunyai daya tarik tersendiri bagi konsumen. Favorability of brand association adalah asosiasi merek dimana konsumen percaya bahwa atribut dan 
manfaat yang diberikan oleh merek akan dapat memenuhi atau memuaskan kebutuhan dan keinginan mereka sehingga mereka membentuk sikap positif terhadap merek.

Hasil penelitian selanjutnya mengenai perbedaan Brand Image yang ditinjau dari Dimensi kekuatan asosiasi merek didapat hasil yaitu $\mathrm{H} 02$ ditolak dan $\mathrm{Ha} 2$ diterima. Artinya tidak ada perbedaan yang signifian antara Brand Image laptop Acer dan Asus ditinjau dari Dimensi kekuatan asosiasi merek. Menurut responden produk laptop Acer dan Asus memiliki kekuatan yang sama-sama memiliki Brand Image yang sudah melekat pada benak para konsumen yang menggunakan produk laptop. Hal ini sesuai dengan teori Keller (2003) mengenai kekuatan asosiasi merek yaitu kekuatan asosiasi merek ini merupakan fungsi dari jumlah pengolahan informasi yang diterima pada proses recoding. Ketika seorang konsumen secara aktif menguraikan arti informasi suatu produk atau jasa maka akan tercipta asosiasi yang semakin kuat pada ingatan konsumen. Pentingnya asosiasi merek pada ingatan konsumen tergantung pada bagaimana suatu merek tersebut dipertimbangkan.

Dari hasil penelitian selanjutnya mengenai perbedaan Brand Image yang ditinjau dari Dimensi keunikan asosiasi merek didapat hasil yaitu $\mathrm{H} 03$ diterima dan Ha3 ditolak. Artinya ada perbedaan yang signifian antara Brand Image laptop Acer dan Asus ditinjau dari Dimensi keunikan asosiasi merek. Dari skor rata-rata yang diperoleh laptop Acer lebih unggul dari pada laptop Asus. Menurut para responden produk laptop Acer lebih unik dari pada Asus dilihat dari persepsi konsumen terhadap produk tersebut, memiliki harga yang sesuai dengan kualitas produk tersebut sehingga memiliki harga jual kembali yang tidak mengalami penurunan yang signifikan, dan memiliki model yang bervariasi. Hal ini sesuai dengan teori Keller (2003) mengenai keunikan asosiasi merek yaitu Keunikan merek adalah asosiasi terhadap suatu merek mau tidak mau harus terbagi dengan merek-merek lain. Oleh karena itu, harus diciptakan keunggulan bersaing yang dapat dijadikan alasan bagi konsumen untuk memilih suatu merek tertentu. Dengan memposisikan merek lebih mengarah kepada pengalaman atau keuntungan diri dari image produk tersebut. Dari perbedaan yang ada, baik dari produk, pelayanan, personil, dan saluran yang diharapkan memberikan perbedaan dari pesaingnya, yang dapat memberikan keuntungan bagi produsen dan konsumen.

Hasil penelitian ini sesuai dengan pendapat Ferindadewi (2008) berpendapat bahwa citra merek merupakan konsep yang diiciptakan oleh konsumen karena alasan subjektif dan emosi pribadinya. Ditambahkan citra merek adalah persepsi tentang merek yang digambarkan oleh asosiasi merek yang ada dalam ingatan konsumen. Citra yang baik terhadap suatu barang akan meningkatkan persepsi yang baik pula terhadap seseorang. Selain itu penelitian ini juga sesuai dengan pendapat dari keller (2003) mengenai faktor-faktor terbentuknya Brand Image (Citra Merek) adalah yang pertama keunggulan asosiasi merek, kedua kekuatan asosiasi merek, dan ketiga keunikan asosiasi merek.

\section{SIMPULAN DAN SARAN Simpulan}

Adapun simpulan dari penelitian ini adalah sebagai berikut. Pertama terdapat perbedaan yang signifikan Brand Image laptop Asus dan Acer pada mahasiswa Fakultas Ekonomi Universitas Pendidikan Ganesha tahun 2017 ditinjau dari dimensi keunggulan assosiasi merek. Kedua Tidak terdapat perbedaan yang signifikan Brand Image laptop Asus dan Acer pada mahasiswa Fakultas Ekonomi Universitas Pendidikan Ganesha tahun 2017 ditinjau dari dimensi kekuatan assosiasi merek, dan ketiga Terdapat perbedaan yang signifikan Brand Image laptop Asus dan Acer pada mahasiswa Fakultas Ekonomi Universitas Pendidikan Ganesha tahun 2017 ditinjau dari dimensi keunikan assosiasi merek.

\section{Saran}

Berdasarkan hasil penelitian yang telah disimpulkan di atas, peneliti dapat 
p-ISSN : 2599-1418

e-ISSN : 2599-1426

memberikan saran sebagai berikut. Bagi Perusahaan untuk para perusahaan yang berada dibidang eletronik khususnya yang memproduksi laptop agar mau memproduksi produk laptop yang mampu bersaing dari spesifikasinya, agar nantinya citra merek dari produk laptop terssebut mampu melekat pada ingatan setiap konsumen. Bagi Akademik untuk peneliti selanjutnya hendaknya lebih memperluas lagi penelitian tentang Brand Image dan memperluas wilayah penelitian karena semakin luas wilayah penelitian maka akan didapatkan hasil yang lebih kongkrit dari suatu wilayah.

\section{DAFTAR PUSTAKA}

Alfian, B. 2012. Pengaruh Citra Merek (Brand Image) Terhadap Pengambilan Keputusan Pembelian Mobil Toyota Kijang Inova Pada PT. Hadji Kalla Cabang Polman. Makasar. Fakultas Ekonomi dan Bisnis. Universitas Hasanuddin. Skripsi tidak diterbitkan.

Anggraeni, F. 2016. Studi Komperatif Brand Loyality Air Minum dalam kemasan Yeh Buleleng dan Aqua Pada mahasiswa Fakultas Ekonomi Universitas Pendidikan Ganesha Universitas Pendidikan Ganesha Tahun 2015/2016. Fakultas Ekonomi, Universitas Pendidikan Ganesha. Skripsi tidak diterbitkan.

Durianto, Darmadi, dkk, 2004. Strategi Menaklukkan Pasar melalui Riset Ekuitas dan Perilaku Merek. Jakarta : PT. Gramedia Pustaka Utama.

Ferindadewi, E. 2008. Merek \& Psikologi Konsumen; Implikasi pada Strategi Pemasaran. Yogyakarta : Graha IImu.

Hasan, A. 2008, Marketing. Yogyakarta : Media Utama.

Iskan, D. 2008. Perilaku Konsumen. Edisi Pertama. Yogyakarta : Graha Ilmu.

Kotler, P. \& Amstrong, G. 2006, Prinsipprinsip Pemasaran. Jakarta : Erlangga.
Jurnal Pendidikan Ekonomi Undiksha

Volume 10 No. 1 Tahun 2018

Lamb, dkk. (2001). Pemasaran. Buku -1. Jakarta : PT. Salemba Emban Raya.

Shimp, T. A. 2003. Periklanan Promosi Aspek Tambahan Komunikasi Pemasaran Terpadu. Jakarta : Erlangga.

Simanora, B. 2001. Memenangkan Pasar dengan Pemasaran Efektif dan Profitabe. Edisi Pertama. Jakarta : PT. Gramedia Pustaka Utama.

Sugiyono. 2009. Statistika Untuk Penelitian. Edisi Kesembilan belas. Jakarta : Alfabeta.

Tjiptono, F. 2005. Strategi Pemasaran. Edisi Kedua. Yogyakarta : Pustaka Belajar.

Umar, H. 2003. Riset Pemasaran dan Perilaku Konsumen. Jakarta : Gramedia Pustaka Utama.

Undang - undang No.15 Tahun 2001 